\title{
SOIL CO EMISSION OF SUGARCANE FIELDS AS AFFECTED BY TOPOGRAPHY
}

\author{
Liziane de Figueiredo Brito ${ }^{1 *}$; José Marques Júnior²; Gener Tadeu Pereira ${ }^{1}$; Zigomar Menezes \\ Souza $^{3}$; Newton La Scala Júnior ${ }^{1}$ \\ ${ }^{I}$ UNESP/FCAV - Depto. de Ciências Exatas, Via de Acesso Prof. Paulo Donato Castellane, s/n - 14884-900 - \\ Jaboticabal, SP - Brasil. \\ ${ }^{2} U N E S P / F C A V$ - Depto. de Solos e Adubos. \\ ${ }^{3}$ UNICAMP/FEAGRI, C.P. 6011 - 13083-875 - Campinas, SP - Brasil. \\ *Corresponding author <liziane@fcav.unesp.br>
}

\begin{abstract}
The spatial and temporal variation of soil $\mathrm{CO}_{2}$ emission is influenced by several soil attributes related to $\mathrm{CO}_{2}$ production and its diffusion in the soil. However, few studies aiming to understand the effect of topography on the variability of $\mathrm{CO}_{2}$ emissions exist, especially for cropping areas of tropical regions. The objective of this study was to evaluate the spatial and temporal changes of soil $\mathrm{CO}_{2}$ emission and its relation to soil attributes in an area currently cropped with sugarcane under different relief forms and slope positions. Mean $\mathrm{CO}_{2}$ emissions in the studied period (seven months) varied between 0.23 and $0.71,0.27$ and 0.90 , and 0.31 and $0.80 \mathrm{~g} \mathrm{~m}^{-2} \mathrm{~h}^{-1}$ of $\mathrm{CO}_{2}$ for concave (Conc), backslope (BackS) and footslope (FootS) positions, respectively. The temporal variability of $\mathrm{CO}_{2}$ emissions in each area was explained by an exponential relation between the $\mathrm{CO}_{2}$ emission and soil temperature and a linear relation between $\mathrm{CO}_{2}$ emission and soil water content. The $Q_{10}$ values were $1.98( \pm 0.34), 1.81( \pm 0.49)$ and $1.71( \pm 0.31)$ for Conc, BackS and FootS, respectively. Bulk density, macroporosity, penetration resistance, aggregation and oxidizable organic carbon content explain the changes in soil $\mathrm{CO}_{2}$ emission observed, especially when the Conc position was compared to BackS. The effect of relief form and topographic position on soil $\mathrm{CO}_{2}$ emission variation was dependent on the time of measurement.
\end{abstract}

Key words: soil respiration, temporal variation, spatial variation, soil attributes, soil porosity

\section{EMISSÃO DE CO $\mathrm{C}_{2}$ DO SOLO SOB CULTIVO DE CANA-DE-AÇÚCAR EMFUNÇÃODA TOPOGRAFIA}

\begin{abstract}
RESUMO: A variação temporal e espacial da emissão de $\mathrm{CO}_{2}$ solo-atmosfera é influenciada por inúmeros atributos do solo relacionados à produção de $\mathrm{CO}_{2}$ e à difusão do gás no solo. Ainda são escassos, entretanto, estudos visando compreender o efeito da topografia na variação da emissão deste gás, especialmente em áreas agrícolas da região tropical. O objetivo deste trabalho foi estudar a variação temporal e espacial da emissão de $\mathrm{CO}_{2}$ solo-atmosfera e sua relação com atributos do solo em área de cultivo de cana-de-açúcar sob diferentes formas de relevo e posições na encosta. A média da emissão de $\mathrm{CO}_{2}$ no período de sete meses de estudo variou entre 0,23 e 0,$71 ; 0,27$ e 0,90 e 0,31 e $0.80 \mathrm{~g} \mathrm{CO}_{2} \mathrm{~m}^{-2} \mathrm{~h}^{-1}$, nas posições côncava (Conc), encosta superior (BackS) e encosta inferior (FootS), respectivamente. A variação temporal da emissão em cada uma das áreas foi explicada por uma relação exponencial entre emissão de $\mathrm{CO}_{2}$ e temperatura do solo, e uma relação linear da emissão deste gás com a umidade do solo. $\mathrm{O}$ valor de $Q_{10}$ foi $1,98( \pm 0,34) ; 1,81( \pm 0,49)$ e 1,71 $( \pm 0,31)$ para Conc, BackS e FootS, respectivamente. Densidade do solo, macroporosidade, resistência do solo à penetração, agregação e conteúdo de carbono orgânico oxidável explicaram as variações observadas na emissão de $\mathrm{CO}_{2}$, especialmente quando se compara a posição côncava com a encosta superior. $\mathrm{O}$ efeito do relevo e da posição topográfica sobre a variação da emissão de $\mathrm{CO}_{2}$ do solo foi dependente da época de amostragem.

Palavras-chave: respiração do solo, variação temporal, variação espacial, atributos do solo, porosidade do solo
\end{abstract}

\section{INTRODUCTION}

Soil $\mathrm{CO}_{2}$ emission is an important component of the global carbon cycle (Raich \& Schlesinger,
1992), which is basically controlled by two processes: $\mathrm{CO}_{2}$ production within the soil and its transport from the soil into the atmosphere (Fang \& Moncrieff, 1999). Microbial activity and root respiration are the major 
sources of $\mathrm{CO}_{2}$ production, and the transport of the gas is governed by diffusion. These processes, in turn, are influenced by several attributes that establish the spatial and temporal variations of soil $\mathrm{CO}_{2}$ emission. Soil temperature and soil water content, or the interaction between both, are the main controlling factors of the variability of soil respiration (Kang et al., 2003; Kang et al., 2000). Besides temperature and water, the spatial variability of soil respiration is also controlled by organic carbon, microbial biomass, root biomass, litter, nutrients $(\mathrm{N}, \mathrm{Mg}, \mathrm{Ca}, \mathrm{P}), \mathrm{pH}$, cation exchange capacity, iron oxide content, bulk density and porosity (Epron et al., 2006; Xu \& Qi, 2001; La Scala Júnior et al., 2000; Fang et al., 1998).

Changes in $\mathrm{CO}_{2}$ emissions and soil chemical, physical and biological properties have been reported to be related to land exposition and slope length (Kang et al., 2006; Kang et al., 2003), microtopography (Jia et al., 2003), slope position (Risch \& Frank, 2006; Hanson et al., 1993), slope angle (Silva et al., 2004) and relief form (Souza et al., 2006; Souza et al., 2004a,b,c; Souza et al., 2003). Such topographic aspects affect ground and underground water flows, constituting the major cause of spatial variability of soil attributes (Daniels \& Hammer, 1992).

Nowadays, in the worldwide scenario, Brazil is the main sugarcane (Saccharum spp.) producer, with 6.96 million cropped hectares. This area represents almost $11.5 \%$ of the total cropped area with the main Brazilian agricultural products. São Paulo is the major sugarcane producer state, with 3.68 million hectares, corresponding to $52.9 \%$ of the total area cropped with sugarcane in Brazil. Considering that the total area cropped with sugarcane increases every year, reaching a $13 \%$ increase in $2007 / 2008$ in relation to $2006 /$ 2007 (Conab, 2008), studying the spatial and temporal changes of soil $\mathrm{CO}_{2}$ emission in such agrosystem is of great interest.

The objective of this work was to identify the topographic effect on spatial and temporal variations of soil $\mathrm{CO}_{2}$ emission in an area currently cropped with sugarcane in the Southeastern region of Brazil, and to determine the soil attributes that control such variations.

\section{MATERIAL AND METHODS}

The experiment was carried out on the Santa Isabel Farm located at $21^{\circ} 17^{\prime}$ to $21^{\circ} 18^{\prime} \mathrm{S}$ and $48^{\circ} 08^{\prime}$ to $48^{\circ} 10^{\prime} \mathrm{W}$, in Jaboticabal, São Paulo state, Brazil, where sugarcane has been cropped for over 60 years and mechanically harvested (green) for over the last ten years. The climate of the region is characterized by tropical rainy summers and dry winters, being clas- sified as Aw by Köepen. The average temperature is $24.3^{\circ} \mathrm{C}$ and $18.8^{\circ} \mathrm{C}$ for January and July, respectively, while the average year precipitation is around 1425 $\mathrm{mm}$, with total monthly precipitations of $239.5 \mathrm{~mm}$ and $25.3 \mathrm{~mm}$ for January and July, respectively. The soil is classified as Typic Eutrustox.

The topography of the area presents two relief forms, one concave occurring in the highest position of the landscape, and the other linear, towards the hillside, as described in Souza et al. (2003). The samplings were performed in a $100 \times 100 \mathrm{~m}$ limited area in the concave form (Conc) and in two positions in the linear form, backslope (BackS) and footslope (FootS) (Figure 1).

Soil $\mathrm{CO}_{2}$ emission measurements were conducted during 17 days, from April 28 (one month after sugarcane plantation) to November 23, 2004, with ten randomized replicates for each area in each sampling day. The evaluations were conducted in the morning $(9-11 \mathrm{~h})$ or in the afternoon $(14-16 \mathrm{~h})$, and in some days with measurements conducted in mornings and afternoons, using a flux chamber (LI-6400$09 \mathrm{CO}_{2}$, LI-COR, NE, USA) according to Healy et al. (1996). The chamber is a closed system with an internal volume of $991 \mathrm{~cm}^{3}$ and soil exposed area of 71.6 $\mathrm{cm}^{2}$, and coupled to a LI-6400 photosynthesis system that analyzes the $\mathrm{CO}_{2}$ concentration by infrared gas absorption. The chamber was placed on the top of PVC soil collars installed in the field, between rows, some days before the measurements, eliminating the $\mathrm{CO}_{2}$ flush out effect due to the ring insertion in soil.

Soil temperature $(\mathrm{T})$ was evaluated by a sensor connected to the chamber on each one of the ten evaluation points of $\mathrm{CO}_{2}$ emission at a depth of $0-0.15$

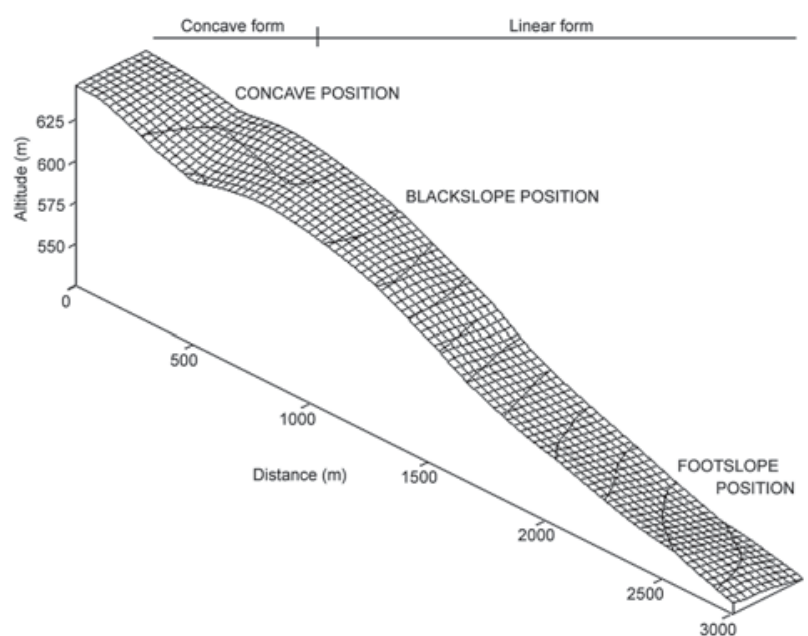

Figure 1 - Altimetric profile covering the concave and linear pedoforms, where the concave backslope and footslope positions were identified. Modified from Souza et al. (2003). 
$\mathrm{m}$ on the 17 sampling days. Gravimetric soil water content (GM) was determined on 11 of the 17 days of study, in the same replicates and depths (Gardner, 1986).

Soil analysis was made on disturbed and undisturbed soil samples, with five replicates in each area. Soil bulk density was determined on undisturbed soil cores $(0.04 \mathrm{~m}$ long and $0.05 \mathrm{~m}$ diameter) (Embrapa, 1997). Total porosity (TP) was calculated based on soil bulk density. Pore size distribution (macroporosity - Macro; microporosity - Micro) was determined based on soil water retention using a tension table (Embrapa, 1997).

Aggregate stability (Kemper \& Rosenau, 1986) was determined by sieving in water, with aggregates that passed through a 7.93-mm sieve and were retained in a $4.76-\mathrm{mm}$ sieve, and then separated in classes using a set of sieves of meshes of $4.76 \mathrm{~mm}, 2 \mathrm{~mm}, 1$ $\mathrm{mm}, 0.5 \mathrm{~mm}$ and $0.25 \mathrm{~mm}$. Results were expressed in terms of geometric mean diameter (GMD), percentage of aggregates larger than $2 \mathrm{~mm}(\varnothing>2 \mathrm{~mm})$, percentage of aggregates between $2-1 \mathrm{~mm}(\varnothing 2-1 \mathrm{~mm})$ and percentage of aggregates smaller than $1 \mathrm{~mm}(\varnothing$ $<1 \mathrm{~mm}$ ).

The soil sampled with an auger was passed through a 2-mm sieve to determine particle-size distribution (pipette and sieving method, after the soil samples had been dispersed chemically in a $0.1 \mathrm{M}$ $\mathrm{NaOH}$ solution and mechanically in low-rotation agitation for 16 hours, modified by Embrapa (1997)), $\mathrm{Fe}_{2} \mathrm{O}_{3}$ content (extracted with sulphuric acid) (Embrapa, 1979) and oxidizable organic carbon content (CO) (Raij et al., 1987).

Penetration resistance (PR) was measured using an impact penetrometer (IAA/PLANALSUCAR STOLF), according to Stolf (1991), with ten replicates in each area, down to the depth of $0.15 \mathrm{~m}$. When performing the penetration resistance tests, soil samples were taken for GM determination, down to the same depth.

All soil attributes were evaluated by the analysis of variance using the following models for each set of response variables: $\left(1^{\text {st }}\right)$ soil $\mathrm{CO}_{2}$ emission, soil temperature and soil water content: $Y_{i j}=m+P_{i}+$ $\operatorname{Error}(a)+T_{j}+P_{i} T_{j}+\operatorname{Error}(b), Y_{i j}$ being the value of each observation, $m$ the general mean, $P$ the effect of the topographic position i, $\operatorname{Error}(a)$ the plot error, $T_{j}$ the effect of time $\mathrm{j}, P_{i} T_{j}$ the effect of the interaction between topographic position and time, $\operatorname{Error}(b)$ the general error; and $\left(2^{\text {nd }}\right)$ for other evaluated attributes: $Y_{i j}=m+P_{i}+\operatorname{Error}($ geral $), Y_{i j}$ being the value of each observation, $m$ the general mean, $P$ the effect of the topographic position i, Error (geral) the general error. Tukey's test was applied for the multiple comparisons of the means with $10 \%$ of probability. All statistical results were obtained by the SAS/Statistical Analysis Systems software package (SAS Institute, 1998).

\section{RESULTS AND DISCUSSION}

\section{Soil $\mathrm{CO}_{2}$ emission variability}

Soil $\mathrm{CO}_{2}$ emission throughout the 7-month period in different landscape positions (Figure 2), had mean values for Conc, BackS and FootS of 0.38, 0.47 and $0.45 \mathrm{~g} \mathrm{CO}_{2} \mathrm{~m}^{-2} \mathrm{~h}^{-1}$ (Table 1), respectively, and their variation during this period was above $200 \%$. The BackS area presented mean emissions values between 0.27 and $0.90 \mathrm{~g} \mathrm{CO}_{2} \mathrm{~m}^{-2} \mathrm{~h}^{-1}$. This variation is a consequence of the local climate. The lowest emissions are observed in the winter (June 20 to September 21, 2004, Figure 2), which is characterized by lower precipitation and temperatures. Campos (2003) reports smaller values for annual means of soil $\mathrm{CO}_{2}$ emission in sugarcane areas in both the traditional slash and burning manual harvesting system $\left(0.13 \mathrm{~g} \mathrm{CO}_{2} \mathrm{~m}^{-2} \mathrm{~h}^{-1}\right)$ and the mechanized harvesting without trash burning $(0.14$ $\left.\mathrm{g} \mathrm{CO}_{2} \mathrm{~m}^{-2} \mathrm{~h}^{-1}\right)$. Despite these lower values, the author also found a variation of $200 \%$ in $\mathrm{CO}_{2}$ emission $(0.07$ to $0.21 \mathrm{~g} \mathrm{CO}_{2} \mathrm{~m}^{-2} \mathrm{~h}^{-1}$ ) throughout the 11-month culture cycle.

The great temporal variability in $\mathrm{CO}_{2}$ emission presented in our study shows the importance of evaluating emissions in different land conditions and time scales. Since $\mathrm{CO}_{2}$ emission is affected by a large number of factors, when extrapolating emissions for larger areas it is important to take into account its spatial and temporal controls, like soil temperature, moisture, texture, litter stocks and topographical position (Sotta et al., 2006). Indirect estimates based on the difference in soil organic carbon stocks are

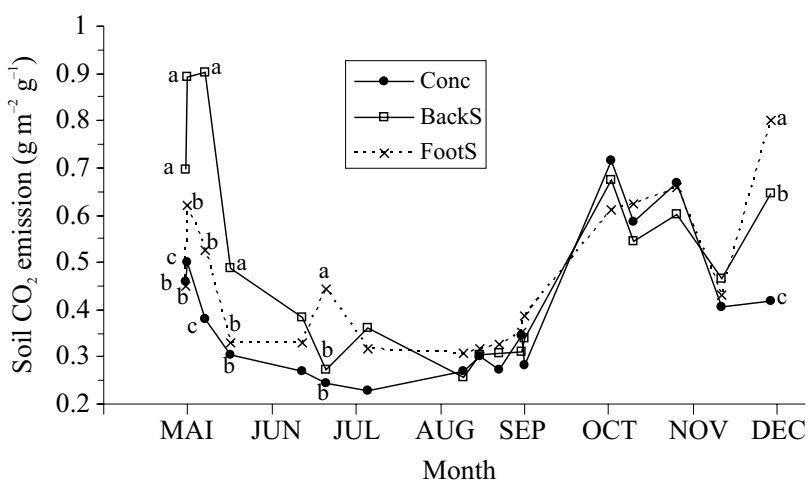

Figure 2 - Soil-atmosphere $\mathrm{CO}_{2}$ emission in the concave (Conc), backslope (BackS) and footslope (FootS) positions. Evaluations performed from April 28 to November 23,2004 . The letters indicate the evaluations where differences in $\mathrm{CO}_{2}$ emission were observed between the positions on the same day (Tukey, $p<0.1$ ). 
Table $1-\mathrm{CO}_{2}$ emission and soil attributes evaluated in the concave, backslope and footslope positions at a depth of $0-0.15 \mathrm{~m}$ on a sugarcane culture area.

\begin{tabular}{|c|c|c|c|c|}
\hline Attribute $^{1}$ & Concave & Backslope & Footslope & $\mathrm{CV}(\%)^{2}$ \\
\hline $\mathrm{CO}_{2} \mathrm{~m}\left(\mathrm{~g} \mathrm{CO}_{2} \mathrm{~m}^{-2} \mathrm{~h}^{-1}\right)$ & $0.38(0.21)$ & $0.47(0.26)$ & $0.45(0.24)$ & 55.21 \\
\hline $\mathrm{T}\left({ }^{\circ} \mathrm{C}\right)$ & $22.47(3.85)$ & $23.01(3.61)$ & $23.62(3.82)$ & 16.43 \\
\hline M (\%) & $21.35(6.18)$ & $21.21(5.96)$ & $20.15(5.82)$ & 28.68 \\
\hline Clay $\left(\mathrm{g} \mathrm{kg}^{-1}\right)$ & $610.00 \mathrm{a}$ & $576.67 \mathrm{a}$ & $606.33 \mathrm{a}$ & 4.79 \\
\hline Silt $\left(\mathrm{g} \mathrm{kg}^{-1}\right)$ & $255.00 \mathrm{a}$ & $256.67 \mathrm{a}$ & $233.67 \mathrm{a}$ & 10.73 \\
\hline Sand $\left(\mathrm{g} \mathrm{kg}^{-1}\right)$ & $135.00 \mathrm{~b}$ & $166.67 \mathrm{a}$ & $160.00 \mathrm{a}$ & 3.26 \\
\hline $\mathrm{BD}\left(\mathrm{kg} \mathrm{dm}^{-3}\right)$ & $1.43 \mathrm{a}$ & $1.22 \mathrm{~b}$ & $1.37 \mathrm{a}$ & 2.91 \\
\hline $\mathrm{TP}\left(\mathrm{m}^{3} \mathrm{~m}^{-3}\right)$ & $0.477 \mathrm{a}$ & $0.491 \mathrm{a}$ & $0.445 \mathrm{a}$ & 11.08 \\
\hline $\operatorname{Micro}\left(\mathrm{m}^{3} \mathrm{~m}^{-3}\right)$ & $0.434 \mathrm{a}$ & $0.399 \mathrm{a}$ & $0.343 \mathrm{a}$ & 15.76 \\
\hline $\operatorname{Macro}\left(\mathrm{m}^{3} \mathrm{~m}^{-3}\right)$ & $0.043 \mathrm{~b}$ & $0.092 \mathrm{a}$ & $0.102 \mathrm{a}$ & 18.41 \\
\hline PR (MPa) & $2.25 \mathrm{a}$ & $1.50 \mathrm{~b}$ & $1.62 \mathrm{ab}$ & 28.24 \\
\hline GMD (mm) & $1.33 \mathrm{~b}$ & $2.05 \mathrm{a}$ & $1.75 \mathrm{ab}$ & 23.92 \\
\hline$\varnothing>2 \mathrm{~mm}(\%)$ & $50.96 \mathrm{~b}$ & $74.77 \mathrm{a}$ & $66.17 \mathrm{ab}$ & 22.49 \\
\hline$\varnothing 2-1$ mm (\%) & $9.94 \mathrm{a}$ & $3.44 \mathrm{~b}$ & $6.17 \mathrm{ab}$ & 62.21 \\
\hline$\varnothing<1 \mathrm{~mm}(\%)$ & $39.10 \mathrm{a}$ & $21.80 \mathrm{~b}$ & $27.66 \mathrm{ab}$ & 37.11 \\
\hline $\mathrm{CO}\left(\mathrm{g} \mathrm{dm}^{-3}\right)$ & $16.47 \mathrm{~b}$ & $20.48 \mathrm{a}$ & $18.15 \mathrm{ab}$ & 12.10 \\
\hline $\mathrm{Fe}_{2} \mathrm{O}_{3}(\%)$ & 15.35 & 19.25 & 21.00 & - \\
\hline
\end{tabular}

${ }^{1} \mathrm{CO}_{2} \mathrm{~m}, \mathrm{~T}$ and $\mathrm{M}$ (mean soil $\mathrm{CO}_{2}$ emission, temperature and moisture over the studied period and their respective standard errors in brackets; BD (bulk density), TP (total porosity), Micro (microporosity), Macro (macroporosity), PR (penetration resistance), GMD (geometric mean diameter), $\varnothing>2 \mathrm{~mm}$ (\% of aggregates with diameter larger than $2 \mathrm{~mm}), \varnothing 2-1 \mathrm{~mm}(\%$ of aggregates with diameter between 2 and $1 \mathrm{~mm}) ; \varnothing<1 \mathrm{~mm}$ (\% of aggregates with diameter smaller than $1 \mathrm{~mm}$ ), $\mathrm{CO}$ (oxidizable organic carbon), $\mathrm{Fe}_{2} \mathrm{O}_{3}(\mathrm{obtained}$ from sulphuric attack). ${ }^{2} \mathrm{CV}$ : coefficient of variation. (Tukey, $p<0.05$ ).

also used for predictions of soil carbon losses. Changes in soil organic carbon stocks due to land use in Brazil were estimated using a map of different soil-vegetation associations combined with results from a soil database (Bernoux et al., 2001, 2002).

Differences $(p<0.1)$ found in mean soil $\mathrm{CO}_{2}$ emissions on a same day, when topographic positions were compared, indicate seasonallity dependence (Figure 2). Hanson et al. (1993) also found differences in $\mathrm{CO}_{2}$ emission in some evaluations, but not for the whole period of study, when comparing emissions from areas in different topographic positions (top, slope or valley). The topography effect on soil $\mathrm{CO}_{2}$ emission was observed especially in the first days of the experiment, when the soil was found almost bare with no vegetation. The fact that the differences in the emissions between the positions were not maintained during the whole experiment is probably related to other factors, such as the contribution of root respiration with the development of the root system of the sugarcane, in agreement with Parkin et al. (2005). According to these authors, root respiration masked the effect of topography on soil $\mathrm{CO}_{2}$ emission, since such effect is greater on maize crops, a grassy crop like sugarcane, than on soybean crops.
During the first days of the experiment, the BackS area presented the highest emissions in relation to those observed in the Conc and FootS areas $(p<$ 0.10 ) (Figure 2), indicating that soil $\mathrm{CO}_{2}$ emission is different in relation to topographic positions. Other authors report a significant increase in soil $\mathrm{CO}_{2}$ emission in the descending direction of the hillside, with higher emissions in the lower positions of the hillslope when compared to top positions. This is related to the contribution of erosion, since, in the lowered parts, an increase in soil surface biomass (Risch \& Frank, 2006), thickness and organic matter content of the A horizons and crop productivity (DeJong, 1981) is observed. However, the increase in $\mathrm{CO}_{2}$ emission in our study did not occur in this direction along the hillside. The soil cover from crop residues has probably provided greater protection against erosion processes, preventing soil loss and reduction in surface organic carbon, since the area in the higher positions presented higher soil $\mathrm{CO}_{2}$ emission and organic carbon content (Table 1). On the other hand, when comparing Conc with linear relief forms (BackS and FootS), it was observed that the relief form did not always determine differences in $\mathrm{CO}_{2}$ emission at the beginning of the experiment, since on some days no difference was observed between Conc and FootS emissions. 


\section{Variation in soil attributes}

BackS had the lowest soil bulk density, highest macroporosity, highest geometric mean particle diameter, highest percentage of aggregates with diameter larger than $2 \mathrm{~mm}$, the smallest percentage of aggregates with diameter between 2 and $1 \mathrm{~mm}$, smallest percentage of aggregates with diameter smaller that 1 $\mathrm{mm}$, smallest soil penetration resistance and highest oxidizable organic carbon content when compared with Conc $(p<0.1)$ (Table 1). Considering the same soil attributes, the values for FootS were between those found for the Conc and BackS areas, differing from BackS in relation to bulk density and from Conc in relation to macroporosity only. These results reinforce the influence of topographic position and/or relief form on soil attributes.

The area presenting the smallest bulk density and penetration resistance and the highest macroporosity was the one that presented the highest $\mathrm{CO}_{2}$ emission (BackS) (Table 1 and Figure 2). This result shows the importance of the soil porous space for gaseous transport and, consequently, for microbial activity, which is in aggreament with the results found by Xu \& Qi (2001). Higher total porosity facilitates oxygen entrance into the soil, favoring respiration and, consequently, increasing $\mathrm{CO}_{2}$ emissions (Fang et al., 1998). Although total porosity values for Conc, BackS and FootS were similar, the highest emissions were observed on the sites with higher macroporosity. This indicates the influence of pore size distribution on emissions, since soil gas diffusion, according to Fick's law: $E_{\mathrm{CO}_{2}}=-D_{\mathrm{CO}_{2}}^{a r}(T P-M)(L / L e)^{2} d C / d x$ (where $E C_{2}$ is the soil $\mathrm{CO}_{2}$ emission, $-D_{C O}^{a r}$ the diffusion coefficient of the gas in the air, $(T P-M)$ the water free porosity, and $(L / L e)_{2}$ the tortuosity factor) (Alvenäs \& Jansson, 1997), is not only dependent on total porosity (TP), but also on tortuosity. Thus, macro and micropore distribution determines the possible trajectories of gases in the soil, affecting both the entrance of $\mathrm{O}_{2}$ and the release of $\mathrm{CO}_{2}$.

Differences observed in $\mathrm{Fe}_{2} \mathrm{O}_{3}$ and oxidizable organic carbon content between topographic positions are coherent with the results obtained for aggregate stability indexes (GMD, $<\varnothing 2 \mathrm{~mm}, \varnothing 2-1 \mathrm{~mm}$ and $<1$ $\mathrm{mm}$, Table 1), confirming the positive relation between these attributes and aggregation (Oades, 1984; Schwertmann \& Taylor, 1989). Despite the physical protection by the organic matter associated with aggregation, the highest $\mathrm{CO}_{2}$ emissions were observed in BackS, which was probably due to the higher oxidizable organic carbon content of this area. A positive association between $\mathrm{CO}_{2}$ emissions and soil organic carbon was also found by Xu \& Qi (2001) and La
Scala Júnior et al. (2000). Yoo et al. (2006) reported higher emissions in relation to higher soil organic carbon content available for microbial activity.

\section{$\mathrm{CO}_{2}$ temporal emission and its relationship with soil temperature and moisture}

Soil temperature throughout the period varied between 17.8 and $30.6^{\circ} \mathrm{C}$, the lowest value being observed in Conc and the highest in FootS. Mean values for each day varied between 17.9 to $30.2^{\circ} \mathrm{C}, 18.8$ to $29.1^{\circ} \mathrm{C}$ and 18.9 to $30.6^{\circ} \mathrm{C}$ for Conc, BackS and FootS, respectively. Comparing the areas, the major differences of daily mean temperature were observed between Conc and FootS, being higher in FootS in 9 of the 17 sampled days (Tukey, $p<0.1$ ). The temperatures for BackS did not differ from the other areas in most of the observations. Considering the data from the 17 evaluations, the coefficient of variation $(\mathrm{CV})$ for temperature was $16.43 \%$. Analyzing the data from each day, this variation is lower, with $\mathrm{CV}$ values between 1.39 and $8.25 \%$, except for one observation where $\mathrm{CV}$ was $13.15 \%$.

The temporal variability of soil $\mathrm{CO}_{2}$ emission in the different positions was explained by an exponential relation of emission to soil temperature (Fang \& Moncrieff, 2001; Xu \& Qi, 2001; Lloyd \& Taylor, 1994). Model $\mathrm{ECO}_{2}=a e$-bTSOIL (Equation 1) was fitted to a linear relationship, thus obtaining a model of the type $\operatorname{Ln}\left(E \mathrm{CO}_{2}\right)=a+b T_{\text {SOIL }}($ Equation 2), which presented the best adjustment based on the coefficient of determination of the model $\left(\mathrm{R}_{2}\right)$ for Conc in relation to other linearly located areas (Table 2). Temperature accounted for 24 to $51 \%$ of the $\mathrm{CO}_{2}$ emission changes, which is related to the smaller variation in soil temperature (CV of 1.39 to $13.15 \%$ ) in relation to the variation of $\mathrm{CO}_{2}$ emission ( $\mathrm{CV}$ of 19.3 to $61.3 \%$ ).

The estimation of $Q_{10}$, which represents the sensitivity of $\mathrm{CO}_{2}$ emission to a 10-degree-celsius increase in soil temperature was calculated by the equation $Q_{10}=e_{10 b}$ (Equation 3) for each topographic position, where $b$ stems from Equation 2 previously presented. The results obtained for Conc, BackS and FootS were $1.98( \pm 0.34), 1.81( \pm 0.49)$ and $1.71( \pm$ 0.31 ), respectively, being close to values previously reported in the literature (Lloyd \& Taylor, 1994; Raich $\&$ Schlesinger, 1992). By comparing topographic positions Conc and BackS, it was observed that Conc presented a lower $Q_{10}$ value and better aggregate stability (Table 1). This result, according to Davidson \& Janssens (2006), may stem from greater physical protection from soil organic matter and, consequently, from a reduction in emission sensitivity in relation to soil temperature in these areas. Nevertheless, when considering the three topographic positions, it was not 
Table 2 - Relation between $\mathrm{CO}_{2}$ emission and soil, temperature $\left({ }^{\circ} \mathrm{C}\right)$ and gravimetric moisture $(\%)$ attributes in the studied topographic positions

\begin{tabular}{|c|c|c|c|c|c|}
\hline \multirow{3}{*}{ Topographic position } & \multicolumn{5}{|c|}{ Estimated Parameters } \\
\hline & \multicolumn{5}{|c|}{$L n_{(E C O 2)}=a+b T_{\text {SOIL }}($ Equation 2$)$} \\
\hline & $\mathrm{a}$ & $\mathrm{b}$ & $\mathrm{R}^{2}$ & $p$ & $Q_{10}=e^{10 b}$ \\
\hline Concave & $-2.556 \pm 0.399$ & $0.068 \pm 0.017$ & 0.51 & 0.001 & $1.98( \pm 0.34)$ \\
\hline Backslope & $-2.166 \pm 0.636$ & $0.059 \pm 0.027$ & 0.24 & 0.044 & $1.81( \pm 0.49)$ \\
\hline \multirow[t]{3}{*}{ Footslope } & $-2.100 \pm 0.438$ & $0.054 \pm 0.018$ & 0.39 & 0.010 & $1.71( \pm 0.31)$ \\
\hline & \multicolumn{5}{|c|}{$E_{(\mathrm{CO} 2)}=a+b M_{\text {SOIL }}($ Equation 4$)$} \\
\hline & $\mathrm{a}$ & $\mathrm{b}$ & & $\mathrm{R}^{2}$ & $p$ \\
\hline Concave & $0.170 \pm 0.142$ & $0.012 \pm$ & & 0.31 & 0.100 \\
\hline Backslope & $0.027 \pm 0.230$ & $0.025 \pm$ & & 0.43 & 0.039 \\
\hline Footslope & $0.386 \pm 0.208$ & $0.006 \pm$ & & 0.04 & $0.563^{\mathrm{NS}}$ \\
\hline
\end{tabular}

$\mathrm{E}\left(\mathrm{CO}_{2}\right)$ : soil $\mathrm{CO}_{2}$ emission; $\mathrm{T}_{\text {SOIL }}$ : soil temperature; $\mathrm{M}_{\text {solL }}$ : soil moisture; $Q_{10}$ : sensitivity of $\mathrm{CO}_{2}$ emission to a $10^{\circ} \mathrm{C}$ increase in soil temperature for each topographic position, where $b$ stems from Equation 2. ${ }^{\mathrm{Ns}}$ : not significative $(p<0.10)$. There is no difference for $\mathrm{CO}_{2}$ emission sensitivity in relation to soil temperature and moisture for the three topographic positions according to the $\mathrm{T}$ test for parallelism and the $\mathrm{F}$ test for coincidence $(p<0.05)$ (Zar, 1999).

possible to draw any conclusions concerning this relationship between aggregation and $Q_{10}$, since FootS presented the lowest $Q_{10}$ value, and did not differ from the other areas in relation to aggregation.

Considering the studied period the mean soil water content varied from 13.2 to $29.7 \%, 14.6$ to $30.5 \%$ and 12.6 to $28.5 \%$ for Conc, BackS and FootS, respectively. Soil water contents were affected by the position in the slope, since the major differences were observed between BackS and FootS (Tukey, $p<0.1$ ). The CV value for the total period was $28.68 \%$, and analyzing the variation during each day, the $\mathrm{CV}$ varied from 5.72 to $24.37 \%$.

The temporal variability of $\mathrm{CO}_{2}$ emission could be explained by a linear relation with soil water content $\left(E\left(\mathrm{CO}_{2}\right)=a+b \mathrm{M}_{\text {SOIL }}\right)$ (Equation 4) in Conc and BackS only $(p<0.1)$ (Table 2$)$. Soil water content accounted for 31 and $43 \%$ of the emission variation for those areas, respectively. The lack of relationship between soil water content and emissions in FootS suggests that the effect of the soil water content is dependent on the topographic position.

In summary, soil temperature affected the temporal changes in soil $\mathrm{CO}_{2}$ emission in all areas while the effect of soil water content was evident only in Conc and BackS. Other researchers report the effect of these factors on emission changes. Soil respiration was dominantly controlled by temperature in a mountain area in China, since the influence of moisture was observed only when it was a limiting factor ( $\mathrm{Li}$ et al., 2007). Reth et al. (2005) also related a relation between soil moisture and $\mathrm{CO}_{2}$ emission only in the dry period of the year. Results obtained in the eastern Amazonian area (Brazil) (Sotta et al., 2006) and in a tropical rainforest (Asia) (Kosugi et al., 2007) show that the temporal variability of soil $\mathrm{CO}_{2}$ efflux was depended mainly on soil water content. Strong effects of soil temperature and soil water content on $\mathrm{CO}_{2}$ were observed in managed forests in Canada (Peng \& Thomas, 2006).

\section{ACKNOWLEDGMENTS}

To FCAV-UNESP Graduated Program in Plant Production; to CAPES, CNPq and FAPESP for financial support; and to Santa Isabel Farm for providing the study area and technical support.

\section{REFERENCES}

ALVENÄS, G.; JANSSON, P.E. Model for evaporation, moisture and temperature of bare soil: calibration and sensitivity analysis. Agricultural and Forest Meteorology, v.88, p.47-56, 1997. BERNOUX, M.; CARVALHO, M.C.S.; VOLKOFF, B.; CERRI, C.C. $\mathrm{CO}_{2}$ emission from mineral soils following land-cover change in Brazil. Global Change Biology, v.7, p.779-787, 2001.

BERNOUX, M.; CARVALHO, M.C.S.; VOLKOFF, B.; CERRI, C.C. Brazil's soil carbon stocks. Soil Science Society of America Journal, v.66, p.888-896, 2002.

CAMPOS, D.C. Potencialidade do sistema de colheita sem queima da cana-de-açúcar para o seqüestro de carbono. Piracicaba: USP/ ESALQ, 2003. 103p. (Doutorado).

COMPANHIA NACIONAL DE ABASTECIMENTO - CONAB. Acompanhamento da safra brasileira de cana-de-açúcar - safra 2007/2008 terceiro levantamento, novembro/2007. Available at: http://www.conab.gov.br/conabweb/download/safra/ 3 levantamento0708 nov2007.pdf. Accessed 21 Jan. 2008.

DANIELS, R.B.; HAMMER, R.D. Soil geomorphology. New York: Jonh Wiley, 1992. 236p.

DAVIDSON, E.A.; JANSSENS, I.A. Temperature sensitivity of soil carbon decomposition and feedbacks to climate change. Nature, v.440, p.165-173, 2006.

DeJONG, E. Soil aeration as affected by slope position and vegetative cover. Soil Science, v.131, p.34-43, 1981 
EMPRESA BRASILEIRA DE PESQUISA AGROPECUÁRIA. Manual de métodos de análise de solo. 2 ed. Rio de Janeiro: Embrapa/CNPS, 1997. 212p.

EMPRESA BRASILEIRA DE PESQUISA AGROPECUÁRIA. Manual de métodos de análise do solo. Rio de Janeiro: Embrapa-SNLCS, 1979. 247p.

EPRON, D.; BOSC, A.; BONAL, D.; FREYCON, V. Spatial variation of soil respiration across a topographic gradient in a tropical rain forest in French Guiana. Journal of Tropical Ecology, v.22, p.565-574, 2006.

FANG, C.; MONCRIEFF J.B.; GHOLZ, H.L.; CLARK, K.L. Soil $\mathrm{CO}_{2}$ efflux and its spatial variation in a Florida slash pine plantation. Plant Soil, v.205, p.135-146, 1998.

FANG, C.; MONCRIEFF, J.B. The dependence of soil $\mathrm{CO}_{2}$ efflux on temperature. Soil Biology and Biochemistry, v.33, p.155-165, 2001.

FANG, C.; MONCRIEFF, J.B. A model for soil $\mathrm{CO}_{2}$ production and transport. 1. Model development. Agricultural and Forest Meteorology, v.95, p.225-236, 1999.

GARDNER, W.H. Water content. In: KLUTE, A. (Ed.) Methods of soil analysis. 2 ed. Madison: ASA, 1986. p.493-541. (Agronomy Monograph, 9).

HANSON, P.J.; WULLSCHLEGER, S.D.; BOHMAN, S.A.; TODD, D.E. Seasonal and topographic patterns of forest floor $\mathrm{CO}_{2}$ efflux from an upland oak forest. Tree Physiology, v.13, p.1-15, 1993.

HEALY, R.W.; STRIEGL, R.G.; RUSSELL, T.F.; HUTCHINSON, G.L.; LIVINGSTON, G. P. Numerical evaluation of static-chamber measurements of soil-atmosphere gas exchange: identification of physical processes. Soil Science Society of America Journal, v.60, p.740-747, 1996.

JIA, S.; AKIYAMA, T.; MO, W.; INATOMI, M.; KOIZUMI, H. Temporal and spatial variability of soil respiration in a cool temperate broadleaved forest. 1. Measurement of spatial variance and factor analysis. Japanese Journal of Ecology, v.53, p.13-22, 2003.

KANG, S.; LEE, D.; LEE, J.; RUNNING, S.W. Topographic and climatic controls on soil environments and net primary in a rugged temperate hardwood forest in Korea. Ecological Research, v.21, p.64-74, 2006.

KANG, S.; DOH, S.; LEE, D.; LEE, D.; JIN, V.L.; KIMBALL, J. Topographic and climatic controls on soil respiration in six temperate mixed-hardwood forest slopes, Korea. Global Change Biology, v.9, p.1427-1437, 2003.

KANG, S.; KIM, S.; DOH, S.; LEE, D. Predicting spatial and temporal patterns of soil temperature based on topography, surface cover and air temperature. Forest Ecology and Management, v.136, p.173-184, 2000.

KEMPER, W.D.; ROSENAU, R.C. Aggregate stability and size distribution. In: KLUTE, A. (Ed.) Methods of soil analysis. 2 ed. Madison: ASA, 1986. p.425-441. (Agronomy Monography, 9).

KOSUGI, Y.; MITANI, T.; ITOH, M.; NOGUCHI, S.; TANI, M.; MATSUO, N.; TAKANASHI, S.; OHKUBO, S.; NIK, A.R. Spatial and temporal variation in soil respiration in a Southeast Asian tropical rainforest. Agricultural and Forest Meteorology, v.147, p.35-47, 2007.

LA SCALA JÚNIOR, N.; MARQUES JÚNIOR, J.; PEREIRA, G.T.; CORÁ, J.E. Carbon dioxide emission related to chemical properties of a tropical bare soil. Soil Biology and Biochemistry, v.32, p.1469-1473, 2000.

LI, H.; YAN, J.; YUE, X.; WANG, M. Significance of soil temperature and moisture for soil respiration in a Chinese mountain area. Agriculture and Forest Meteorology, v.148, p.490-503, 2008.

LLOYD, J.; TAYLOR, J.A. On the temperature-dependence of soil respiration. Functional Ecology, v.8, p.315-323, 1994.

OADES, J.M. Soil organic matter and structural stability: mechanisms and implications for management. Plant and Soil, v.76, p.319-337, 1984.

PARKIN, T.B.; KASPAR, T.C.; SENWO, Z.; PRUEGER, J.H.; HATFIELD, J.L. Relationship of soil respiration to crop and landscape in the walnut creek watershed. Journal of Hydrometeorology, v.6, p.812-824, 2005.
PENG, Y.; THOMAS, S.C. Soil $\mathrm{CO}_{2}$ efflux in uneven-aged managed forests: temporal patterns following harvest and effects of edaphic Heterogeneity. Plant and Soil, v.289, p.253-264, 2006.

RAIJ, B. van; QUAGGIO, J.A.; CANTARELLA, H.; FERREIRA, M.E.; LOPES, A.S.; BATAGLIA, C.O. Análise química do solo para fins de fertilidade. Campinas: Fundação Cargill, 1987. 170p.

RAICH, J.W.; SCHLESINGER, W.H. The global carbon dioxide flux in soil respiration and its relationship to climate. Tellus, v.44B, p.81-99, 1992.

RETH, S.; MARKUS, R.; FALGE, E. The effect of soil water content, soil temperature, soil $\mathrm{pH}$-value and the root mass on soil $\mathrm{CO}_{2}$ efflux: a modified model. Plant and Soil, v.268, p.2133,2005

RISCH, A.C.; FRANK, D.A. Carbon dioxide fluxes in a spatially and temporally heterogeneous temperate grassland. Oecologia, v.147, p.291-302, 2006.

SAS INSTITUTE. SAS/STAT: user's guide. Cary: SAS Institute, 1998.

SCHWERTMANN, U.; TAYLOR, R.M. Iron oxides. In: DIXON, J. B.; WEED, S. B. (Ed.) Minerals in soil environments. Madison: SSSA, 1989. p.379-438.

SILVA, A.C.; TORRADO, P.V.; MARTIN-NETO, L.; VASQUEZ, F.M.; PÉREZ, M.G. Soil organic matter and geomorphic surface stability relationship in an oxisol toposequence (SE-Brazil). In: INTERNATIONAL MEETING OF THE INTERNATIONAL HUMIC SUBSTANCES SOCIETY, 12., São Pedro, 2004. Proceedings. São Carlos: Embrapa Instrumentação Agropecuária, 2004. v.1, p.623-626.

SOTTA, E. D.; VELDKAMP, E.; GUIMARÃES, B. R.; PAIXÃO, R. K.; RUIVO, M. L.P.; ALMEIDA, S.S. Landscape and climatic controls on spatial and temporal variation in soil $\mathrm{CO}_{2}$ efflux in an Eastern Amazonian Rainforest, Caxiuanã, Brazil. Forest Ecology and Management, v.237, p.57-64, 2006.

SOUZA, C.K.; MARQUES JÚNIOR, J.; MARTINS FILHO, M.V.; PEREIRA, G.T. Influência do relevo e erosão na variabilidade espacial de um latossolo em Jaboticabal (SP). Revista Brasileira de Ciência do Solo, v.27, p.1067-1074. 2003.

SOUZA, Z.M.; MARQUES JÚNIOR, J.; PEREIRA, G.T.; MOREIRA, L.F. Influência da pedoforma na variabilidade espacial de alguns atributos físicos e hídricos de um Latossolo sob cultivo de cana-de-açúcar. Irriga, v.9, p.1-11, 2004c.

SOUZA, Z.M.; MARQUES JÚNIOR, J.; PEREIRA, G.T.; BARBIERI, D. M. Small relief shape variations influence spatial varaibility of soil chemival attributes. Scientia agricola, v.63, p.161$168,2006$.

SOUZA, Z.M.; MARQUES JÚNIOR, J.; PEREIRA, G.T. Variabilidade espacial da estabilidade de agregados e matéria orgânica em solos de relevos diferentes. Pesquisa Agropecuária Brasileira, v.39, p.491-499, 2004a.

SOUZA, Z.M.; MARQUES JÚNIOR, J.; PEREIRA, G.T.; BENTO, M.J.C. Variabilidade espacial de atributos físicos de um Latossolo Vermelho sob cultivo de cana-de-açúcar. Revista Brasileira de Engenharia Agrícola e Ambiental, v.8, p.51-58, $2004 \mathrm{~b}$.

STOLF, R. Teoria e teste experimental de fórmulas de transformação dos dados de penetrômetro de impacto em resistência do solo. Revista Brasileira de Ciência do Solo, v.15, p.229-235, 1991.

XU, M.; QI, Y. Soil-surface $\mathrm{CO}_{2}$ efflux and its spatial and temporal variations in a young ponderosa pine plantation in northern California. Global Change Biology, v.7, p.667-677, 2001.

YOO, G.; SPOMIER, L.A.; WANDER, M.M. Regulation of carbon mineralization rates by soil structure and water in an agricultural field and a prairie-like soil. Geoderma, v.135, p.16-25, 2006.

ZAR, J.H. Biostatistical analysis. 4 ed. Upper Saddle River: Prentice Hall, 1999. 718p.

Received October 10, 2007

Accepted June 27, 2008 